\title{
5
}

\section{Recent Trends in Ecosystem Services in Coastal Bangladesh}

\author{
John A. Dearing and Md. Sarwar Hossain
}

\subsection{Introduction}

The Bangladesh coastal zone is a highly dynamic system. Recorded statistics list 174 natural disasters during the period 1974-2007 (Rahman et al. 2010), and an estimated one million deaths as a consequence of cyclones in the period 1960-1990 (Ericksen et al. 1996). Floods in 1998 caused losses of buildings and infrastructure worth two billion United States dollars (USD) (Chowdhury 2001). The area of land lost through riverbank erosion through the period 1996-2000 led to financial losses totalling 540 million USD (Salim et al. 2007). The world's largest mangrove forest, the

\footnotetext{
The original version of this chapter was revised. The second author's name was incorrect.

The chapter has been updated with the correct name of the author. An erratum to this chapter can be found at https://doi.org/10.1007/978-3-319-71093-8_30
}

\section{J. A. Dearing $(\bowtie)$}

Geography and Environment, Faculty of Social, Human and Mathematical Sciences, University of Southampton, Southampton, UK

Md. Sarwar Hossain

Institute of Geography, University of Bern, Bern, Switzerland 
Sundarbans, provides a livelihood for around three million people (Iftekhar and Islam 2004; Iftekhar and Saenger 2008) and protects more than ten million people from cyclonic storms. But the forest is vulnerable to cyclone damage, as in 2007 when around 36 per cent of the mangrove area was severely damaged leading to losses of livelihood (CEGIS 2007). Food security has also been severely compromised by climate extremes. Around one million tons of food grain were lost to drought in 1997 and 50 per cent of all grain in 1982 was damaged by flood (Islam et al. 2011). These catastrophic impacts serve to underline the vulnerability of the zone to extreme events but give only a partial picture of the longer-term interactions between society and the environment that may affect the zone's resilience. For example, there are major concerns about the individual and combined effects of shrimp farms, irrigation and flood dykes on regional salinity levels that may in turn constrain freshwater availability and crop productivity.

Hence, long-term perspectives are a prerequisite for understanding social-ecological system dynamics, developing and testing simulation models, and defining safe operating spaces for the region as it moves towards meeting the Sustainable Development Goals (SDGs-UN $2015)$ by 2030 . This chapter reviews historical trends in ecosystem services and changes in human development over the past few decades that underlie these statistics (Hossain et al. 2016a, b). The chapter summarises social-ecological dynamics including preliminary analyses of trade-offs between economic growth, well-being and ecosystem services.

\subsection{Location and Data Sources}

The south-west coastal zone as defined in this study comprises the modern districts of Satkhira, Khulna, Bagerhat, Pirojpur, Barguna, Jhalokati, Patuakhali, Barisal and Bhola within the divisions of Barisal and Khulna (see Chap. 4, Figs. 4.1 and 4.2). The zone covers an area of $-25,500 \mathrm{~km}^{2}$ with a total population of around 14 million and population densities ranging from 400 to 800 people $/ \mathrm{km}^{2}$ (BBS 2012). The Sundarbans mangrove forest (a UNESCO World Heritage Site) extends across $6,000 \mathrm{~km}^{2}$ of the southern parts of this area.

Indicators of ecosystem services across the zone (Table 5.1 and Fig. 5.1) are classified as provisioning services or regulating and habitat services. Different 
Table 5.1 Data sources for ecosystem services and specific indicators. Where possible, aggregate district-level data collected since 1985 from the nine districts are aggregated into three sets that are equivalent to the three larger 'greater districts' or 'regions' of Barisal, Khulna and Patuakhali, which existed before 1985. $\mathrm{T}=$ traditional varieties. $\mathrm{HYV}=$ high-yielding varieties (see Hossain et al. 2016a for data sources)

\begin{tabular}{|c|c|c|c|}
\hline $\begin{array}{l}\text { Ecosystem } \\
\text { services }\end{array}$ & Indicators & $\begin{array}{l}\text { Temporal } \\
\text { scale }\end{array}$ & Data sources \\
\hline \multicolumn{4}{|c|}{ Provisioning services } \\
\hline $\begin{array}{l}\text { Food } \\
\text { production }\end{array}$ & $\begin{array}{l}\text { Rice (T-and HYV-Aus, } \\
\text { T-and HYV-Aman, } \\
\text { T-and HYV-Boro) } \\
\text { Vegetables } \\
\text { Potato } \\
\text { Sugarcane, jute, } \\
\text { onion, spices (garlic, } \\
\text { ginger, turmeric } \\
\text { and coriander) } \\
\text { Fish } \\
\text { Shrimp } \\
\text { Honey }\end{array}$ & $\begin{array}{l}\text { Total rice } \\
1948-2010 \\
\text { Rice varieties } \\
\text { 1969-2010 }\end{array}$ & $\begin{array}{l}\text { Bangladesh Bureau of } \\
\text { Statistics }\end{array}$ \\
\hline $\begin{array}{l}\text { Forest } \\
\text { products } \\
\text { Regulating se }\end{array}$ & $\begin{array}{l}\text { Timber types } \\
\text { (Glopata, Goran, } \\
\text { Gewa) } \\
\text { Beeswax } \\
\text { rvices }\end{array}$ & 1974-2010 & $\begin{array}{l}\text { Department of Forest, } \\
\text { Khulna, Bangladesh; } \\
\text { Zmarlicki 1994; Chaffey } \\
\text { et al. } 1985\end{array}$ \\
\hline $\begin{array}{l}\text { Water } \\
\text { quality }\end{array}$ & $\begin{array}{l}\text { Surface water salinity } \\
\text { Soil salinity }\end{array}$ & 1964-2006 & $\begin{array}{l}\text { Uddin and Haque 2010; } \\
\text { Islam } 2008\end{array}$ \\
\hline Local climate & $\begin{array}{l}\text { Temperature and } \\
\text { precipitation }\end{array}$ & 1949-2007 & $\begin{array}{l}\text { Bangladesh Meteorological } \\
\text { Department }\end{array}$ \\
\hline $\begin{array}{l}\text { Water } \\
\text { availability }\end{array}$ & $\begin{array}{l}\text { River discharge } \\
\text { Groundwater level }\end{array}$ & 1934-2010 & $\begin{array}{l}\text { Bangladesh Water } \\
\text { Development Board }\end{array}$ \\
\hline $\begin{array}{l}\text { Natural } \\
\text { hazard } \\
\text { protection }\end{array}$ & $\begin{array}{l}\text { Crop damage (due to } \\
\text { cyclones, flooding, } \\
\text { water logging and } \\
\text { excessive rainfall) }\end{array}$ & 1970-2010 & $\begin{array}{l}\text { Bangladesh Bureau of } \\
\text { Statistics }\end{array}$ \\
\hline $\begin{array}{l}\text { Erosion } \\
\text { protection } \\
\text { Habitat servic }\end{array}$ & $\begin{array}{l}\text { Fluvial erosion and } \\
\text { accretion } \\
\text { es }\end{array}$ & 1963-2009 & $\begin{array}{l}\text { Mapped data; Rahman } \\
\text { et al. } 2011\end{array}$ \\
\hline $\begin{array}{l}\text { Maintenance } \\
\text { of } \\
\text { biodiversity }\end{array}$ & $\begin{array}{l}\text { Mangrove density } \\
\text { Mangrove volume } \\
\text { Mangrove area } \\
\text { Mangrove floristic } \\
\text { composition } \\
\text { Tiger numbers } \\
\text { Deer numbers }\end{array}$ & 1960-1997 & $\begin{array}{l}\text { MoEF 2002; FAO 1999; } \\
\text { Khan 2005; MoEF 2010; } \\
\text { FAO 2007; Dey 2007; } \\
\text { Chowdhury 2001; } \\
\text { Helalsiddiqui 1998; } \\
\text { Hendrichs 1975; } \\
\text { Gittins } 1980\end{array}$ \\
\hline \multicolumn{4}{|c|}{ Cultural services } \\
\hline $\begin{array}{l}\text { Recreational } \\
\text { services }\end{array}$ & $\begin{array}{l}\text { Number of tourist } \\
\text { visitors }\end{array}$ & 2000-2009 & $\begin{array}{l}\text { IUCN 1997; Department of } \\
\text { Forest, Khulna }\end{array}$ \\
\hline
\end{tabular}



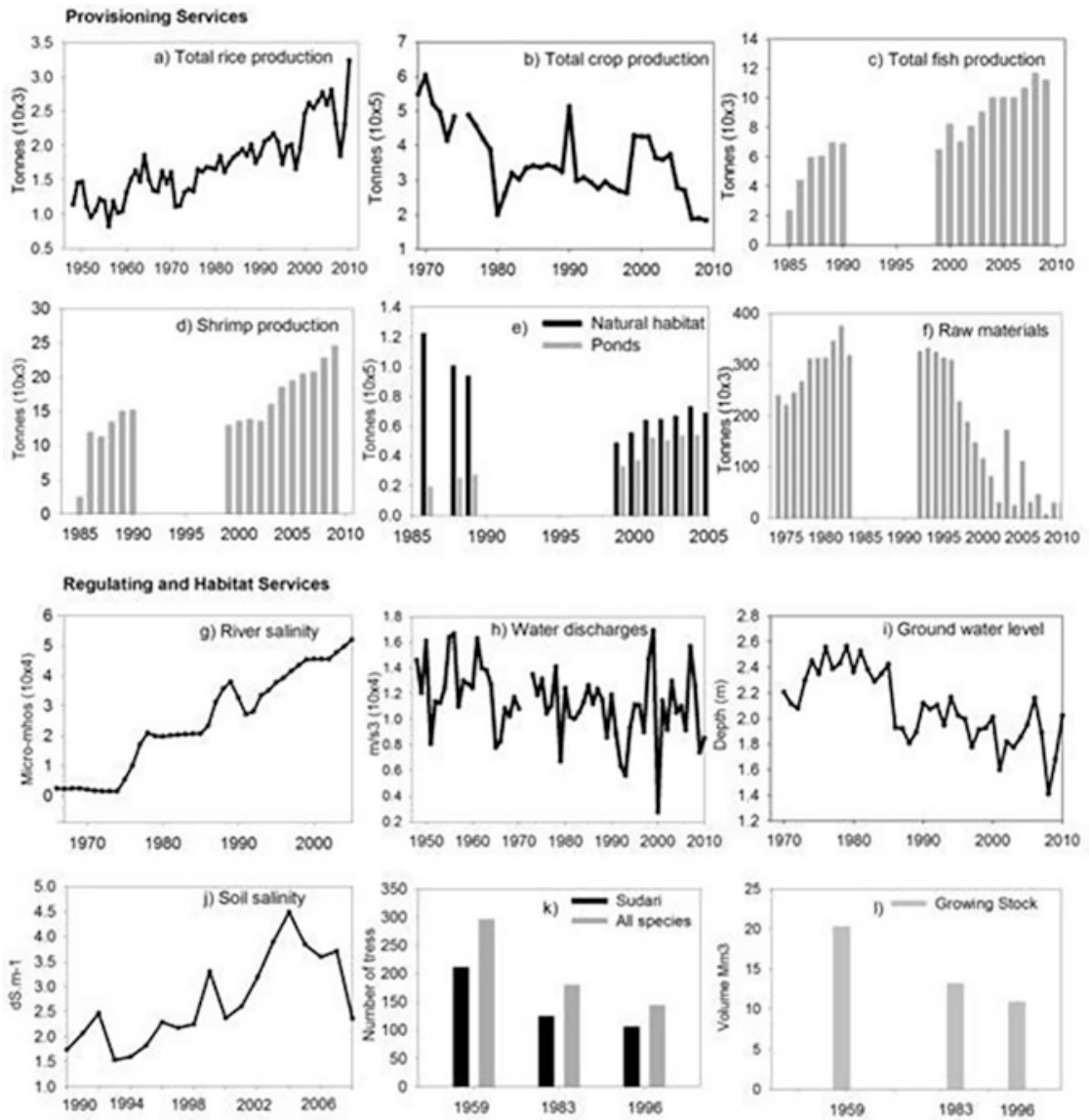

Fig. 5.1 Provisioning, regulating and habitat ecosystem services over recent decades: (a) total rice production, (b) total crop production, (c) total fish production, (d) shrimp production, (e) aquacultural production from natural wetlands and artificial ponds, (f) production of natural forest materials, (g) monitored salinity in the Poshur river at Mongla (Khulna), (h) mean annual river discharge in the Lower Meghna-Ganges river at Hardinge Bridge, (i) monitored depth to groundwater at Dacope (Khulna), (j) average monitored soil salinity at seven sites in Khulna and Patuakhali, (k) monitored tree numbers at an experimental plot in the Sundarbans, (I) estimated volume of growing mangrove in the Sundarbans (see Hossain et al. 2016a for data sources) 
food and forest produce, such as rice, fish and timber, are selected to show the trajectories of provisioning services. Water salinity, river discharge, groundwater levels, crop damage and erosion and accretion rates are used as indicators of regulating services. Tree density and growing stock data for main two mangrove species (Heritiera fomes and Excoecaria agallocha known locally as Sundri and Gewa, respectively) and all species of the mangrove are selected for biodiversity indicators along with the numbers of two globally endangered mammal species (Royal Bengal tigers and deer) in the mangrove forest. External environmental drivers (Fig. 5.3) include mean annual temperature and rainfall, sea level and data for cyclone frequency and magnitude. Data are drawn from annual official data available for the nine districts and the Sundarbans National Park, and partly from ad hoc time-series of monitored point data or sequences of mapped data from hydrological, climatological and agricultural organisations and other scientific studies.

The list of human well-being indicators (Table 5.2 and Fig. 5.2) are selected according to the Millennium Development Goals for Bangladesh (MDG 2015). Data for income, sanitation, electricity, safe drinking water, crop production and production cost at the household level are drawn from Household Income and Expenditure Survey (HIES) datasets collected by the Bangladesh Bureau of Statistics and World Bank in 1995/96, 2000, 2005 and 2010. Data for child and infant mortality, maternal health, education and access to media come from the Demographic and Health Surveys collected in 1993, 1996, 2000, 2004, 2007 and 2010. ${ }^{1}$ Although the Demographic and Health Survey data are at divisional level, two divisions (Khulna and Barisal) have been used for analysing the indicators as the study area covers all districts of Barisal division and around 65 per cent of the total area of Khulna division. Continuous series data are normalised (z-scores) to allow comparisons of curve shapes. Full details of these and other data analyses are available in Hossain et al. (2016a, b).

\subsection{Ecosystem Services and Drivers}

\subsubsection{Provisioning Services}

Food production is mainly derived from agricultural and aquacultural goods with a small amount directly from natural goods (e.g. wild fish, honey). Since 1970, the cultivated crop area has fluctuated between 
Table 5.2 Human well-being indicators based on MEA (2005) and OECD (2013) classifications (see Hossain et al. 2016a for details of data sources)

\begin{tabular}{|c|c|c|c|c|}
\hline \multicolumn{2}{|c|}{ Dimension } & \multirow[b]{2}{*}{ Indicators } & \multirow{2}{*}{$\begin{array}{l}\text { Temporal } \\
\text { scale }\end{array}$} & \multirow[b]{2}{*}{ Data source } \\
\hline MA & OECD & & & \\
\hline Health & $\begin{array}{l}\text { Quality of } \\
\text { life }\end{array}$ & $\begin{array}{l}\text { Child mortality } \\
\text { (probability of dying } \\
\text { before the first birth } \\
\text { day) } \\
\text { Infant mortality } \\
\text { (probability of dying } \\
\text { between the first } \\
\text { and fifth birth day) } \\
\text { Proportion of births } \\
\text { attended by skilled } \\
\text { health personnel (\%) }\end{array}$ & 1993-2011 & $\begin{array}{l}\text { Demographic } \\
\text { health surveys }\end{array}$ \\
\hline \multirow[t]{3}{*}{ Material } & $\begin{array}{l}\text { Material } \\
\text { condition }\end{array}$ & $\begin{array}{l}\text { Sector-wise household } \\
\text { income } \\
\text { Production cost }\end{array}$ & 1995-2010 & $\begin{array}{l}\text { Authors' own } \\
\text { calculations from } \\
\text { household } \\
\text { income and } \\
\text { expenditure } \\
\text { survey } \\
\text { Income from } \\
\text { shrimp farms and } \\
\text { production cost; } \\
\text { (Islam 2007) }\end{array}$ \\
\hline & & $\begin{array}{l}\text { Gross domestic } \\
\text { product (GDP) }\end{array}$ & 1974-2005 & $\begin{array}{l}\text { Bangladesh Bureau } \\
\text { of Statistics }\end{array}$ \\
\hline & & $\begin{array}{l}\text { Poverty-percentage } \\
\text { of people living } \\
\text { below the upper and } \\
\text { lower poverty } \\
\text { thresholds }\end{array}$ & $1983-2010$ & $\begin{array}{l}\text { Bangladesh Bureau } \\
\text { of Statistics } \\
\text { (Wodon 1997) }\end{array}$ \\
\hline Security & $\begin{array}{l}\text { Quality of } \\
\text { life } \\
\text { (personal } \\
\text { security) }\end{array}$ & $\begin{array}{l}\text { Access to electricity, } \\
\text { sanitation, drinking } \\
\text { water source }\end{array}$ & 1995-2010 & $\begin{array}{l}\text { Authors' own } \\
\text { calculations from } \\
\text { Household } \\
\text { Income and } \\
\text { Expenditure } \\
\text { Survey data }\end{array}$ \\
\hline $\begin{array}{l}\text { Freedom } \\
\text { of } \\
\text { choice } \\
\text { and } \\
\text { action }\end{array}$ & $\begin{array}{l}\text { Quality of } \\
\text { life }\end{array}$ & $\begin{array}{l}\text { Education ( } \% \text { of } \\
\text { people completed } \\
\text { primary education)- } \\
\text { man and women } \\
\text { Access to mass media } \\
\text { (television and } \\
\text { newspaper) }\end{array}$ & 1993-2011 & $\begin{array}{l}\text { Demographic } \\
\text { health surveys }\end{array}$ \\
\hline
\end{tabular}




\section{Drivers}
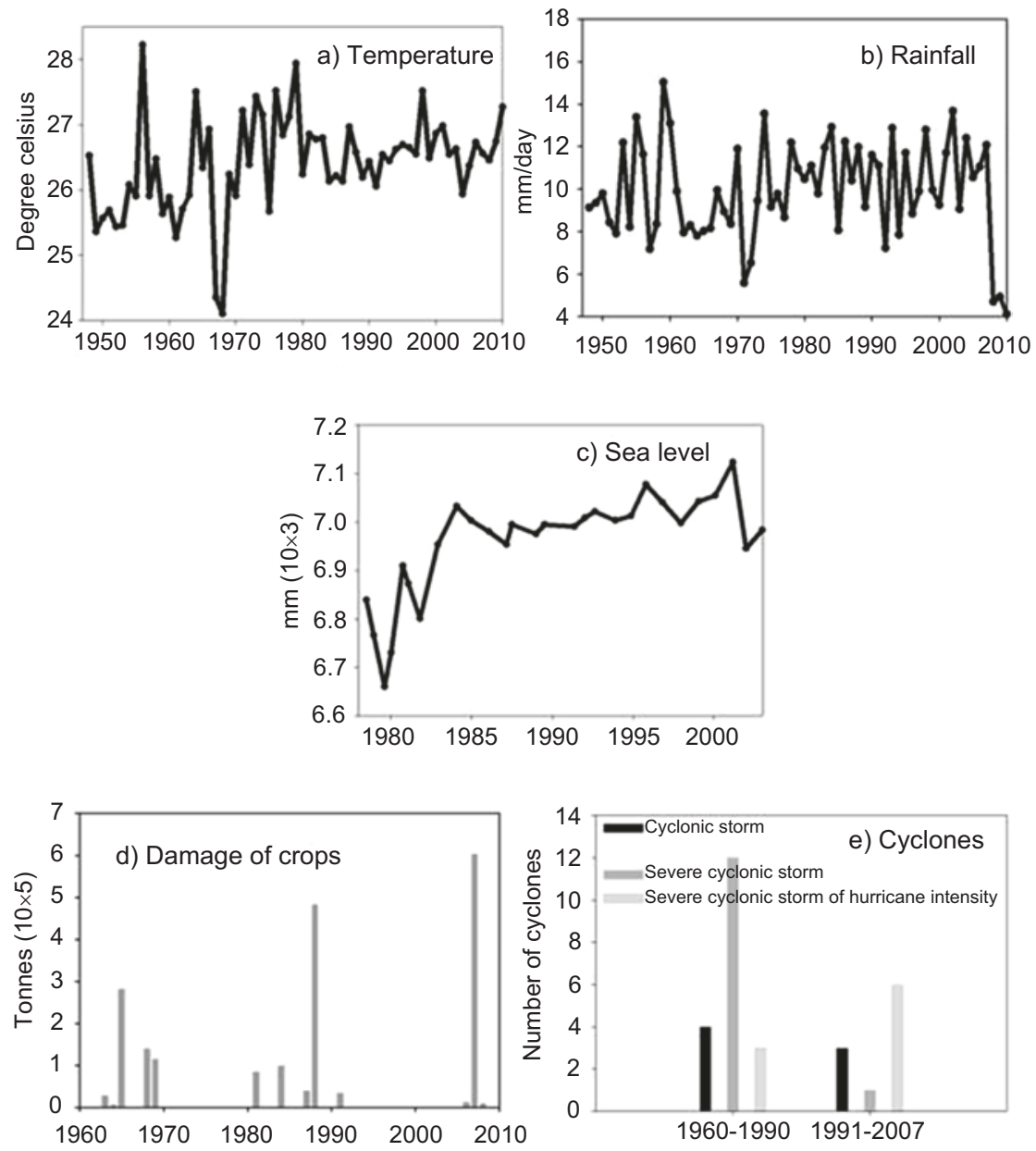

Fig. 5.2 Selected indicators of environmental drivers: (a) mean annual temperature, (b) mean annual rainfall, (c) averaged annual sea level curve (Hiron Point and Khepupara; Brammer 2014), (d) damage to crops, (e) cyclone frequency and intensity (see Hossain et al. 2016a for data sources)

10,000 and $12,000 \mathrm{~km}^{2}$ and in 2009 represents around 47 per cent of the total land area. Despite this relatively stable crop area, regional rice production (Fig. 5.1a) rose five-fold between 1969 and 2010 as traditional rice varieties were replaced by high-yielding varieties. Similar records for 
sugarcane and jute production show declining trends since the 1970s, whilst production figures for both summer and winter vegetables and spices have risen since the 1990s. About 100,000 tonnes (t) of fish and shrimp are produced each year, around 30 per cent from rivers and estuaries, five per cent from the natural wetlands, with the majority (65 per cent) from artificial ponds and fish farms. However, since the 1990s, data show that annual shrimp production has increased from 5,000 to more than 25,000 t, and fish production from ponds has risen from 22,000 to 60,000 t (Fig. 5.1c, d). Production from rivers and estuaries has declined dramatically, reflecting the increased production from artificial ponds and shrimp farms that continues to the present (Fig. 5.1e). Current shrimp and fish production figures are significantly higher in Khulna $(>20,000 \mathrm{t})$ than Barisal $(<50 \mathrm{t})$ and Patuakhali $(<900 \mathrm{t})$. Trends in timber and other natural materials from the Sundarbans reached a maximum in the 1980s before declining steeply after 1997 (Fig. 5.1f). Honey collection shows relatively low values in the 1970s and 1980s, but has increased by $1.7 \mathrm{t}$ per year over the period 1974-2010.

\subsubsection{Regulating and Habitat Services}

Current concerns about regulating and habitat services mainly revolve around water quality, especially salinity and nutrient levels, water availability in terms of availability as river discharge, and water drainage in terms of high groundwater levels. Additionally, some riverside and coastal areas are losing land to erosion processes, and there are concerns that biodiversity, especially across the Sundarbans, is declining. Although only a few long-term records of salinity are available, making extrapolation or averaging of data across the region difficult, some datasets point to general trends. For example, annual mean river water salinity in the Poshur river at Mongla in Khulna (Fig. 5.1g) increased steadily from approximately $<5$ deciSiemens per metre $(\mathrm{dS} / \mathrm{m})$ in the early 1970 s to approximately $>50 \mathrm{dS} / \mathrm{m}$ in 2005. Similar salinity levels were found in rivers in the Rampal and Paikgacha areas until 1995 (Hossain et al. 2016a), but these were followed by a steep decline in the late 1990s. Soil salinity measured during dry (Dec.-May) and wet seasons (June-Nov.) in Khulna 
and Patuakhali since the 1990s shows contrasting records (Hossain et al. 2016b). In Khulna, three sites show salinity values increasing from $<5 \mathrm{dS} / \mathrm{m}$ to reach peak values $>10 \mathrm{dS} / \mathrm{m}$ in the $2000 \mathrm{~s}$, with maximum annual figures exceeding $20 \mathrm{dS} / \mathrm{m}$. Four sites in the Patuakhali region show lower absolute values $(<5 \mathrm{dS} / \mathrm{m})$, even though it is closer to the coast than Khulna, with only slightly rising trends towards the present. Averaging all the records suggests rising salinity values from the 1990 s until 2004 with recent values falling back (Fig. 5.1j). There are no data for actual fertiliser applications, but modelled nutrient loading (total fertiliser and manure input) for three locations in the study area (using the Global NEWS model ${ }^{2}$ ) suggests more than a doubling in the application of fertiliser and manure between 1970 and 2000: $18 \mathrm{t} / \mathrm{km}^{2} /$ year in 1970 to $39 \mathrm{t} / \mathrm{km}^{2} /$ year in 2000 (Hossain et al. 2016b). Construction of the Farakka Barrage on the Ganges in India in 1975 has caused mean annual discharge measured downstream at Hardinge Bridge to the north of the region (Fig. 5.1) to gradually decline (Fig. 5.1h). In particular, dry season river discharge has effectively halved from 2,000-4,000 m³/s before 1975 to $<1,000-2,000 \mathrm{~m}^{3} / \mathrm{s}$ afterwards: an overall rate change only reversed temporarily by extreme flood events in 2000-2001 and 2007. Groundwater levels show markedly different trends. At one site in Khulna (Fig. 5.1i), and another in Barisal, the groundwater levels have been rising (depth below ground decreasing) since the 1980s and now come within $1.5 \mathrm{~m}$ of the surface in the post-monsoon season. But at two other sites, groundwater levels are fairly constant at one and gradually deepening at another (Hossain et al. 2016b). In terms of land losses, geomorphological mapping along the major rivers since the 1970s shows that erosion has been greater than accretion in all decades except the 1980s. Mean erosion rates have decreased from $23 \mathrm{~km}^{2} /$ year in the $1970 \mathrm{~s}$ to $<10 \mathrm{~km}^{2} /$ year in the $2000 \mathrm{~s}$, while mean accretion rates have also declined from 9 to $3 \mathrm{~km}^{2} /$ year over the same period. The most recent estimate of net land loss in the study area adjacent to the rivers is around $6 \mathrm{~km}^{2} /$ year. However, there is also evidence that accretion rates around the Meghna estuary show a land gain of approximately $3 \mathrm{~km}^{2} /$ year since 2001 . The total area of mangroves has increased over the period 1959-2000, while mangrove tree density and numbers (Fig. $5.1 \mathrm{k}$ ) appear to have declined substantially leading to a halving in the estimated growing stock 
(Fig. 5.11). Numbers of deer in the mangrove forest show fluctuating figures (between 50,000 and 95,000) since 1975, but numbers of tigers seem to have peaked at 450 in 1982 and 2004 with a decline to 200 in 2007. Data for the total number of tourists visiting the Sundarbans between 1996 and 2004 show around 5,000 visitors/year from 1996 to 2004 growing to 25,000 per year in the period 2010-2011.

\subsubsection{Environmental Drivers}

Local climate has changed significantly over past decades. Mean annual temperature data from three stations since 1948 show a significantly increasing trajectory in all four seasons (Fig. 5.2a). Averaged mean daily rainfall figures show no major trend and are generally in the range $8-12 \mathrm{~mm} /$ day (Fig. 5.2b) with extreme lows ( $<5 \mathrm{~mm} /$ day) in Khulna in 1971 and 2008-2010 and extreme highs (>45 mm/day) in Barisal in 1955 and 1960, and in Patuakhali in 1983. Monsoon and post-monsoon seasonal rainfall trends generally increased from the mid-1960s to the 1990 s followed by sharply declining trends since 2007 . There is some evidence for a shift in rainfall from the monsoon to the post-monsoon period after the 1990s, but all seasons show a decline after 2007 (Hossain et al. 2016b). The mean sea level from two coastal sites shows a gradual rise since the 1980s (Fig. 5.2c) threatening the ecosystem services at the coast particularly in concert with cyclones. The doubling in the frequency of severe cyclonic storms over the period 1991-2007 compared to 1960-1990 (Fig. 5.2e) is particularly noteworthy. Crop damage from natural disasters (Fig. 5.2d), including flooding, cyclones and waterlogging, since 1963 shows recorded damage in 35 per cent of the years with three clusters around 1963-1969, 1981-1991 and 2006-2009. The last two of these disasters are linked to the impacts of the extreme floods in 1987-1988 and super-cyclone Sidr in 2007.

\subsection{Social Trends and Well-Being}

The population of the coastal zone of Bangladesh was approximately 14 million in the 2011 census with 80 per cent designated as rural population. The total population decreased marginally between 1974 and 1991 
to around eight million before rising to the current level. Total gross domestic product (GDP) across the zone has also increased from 74 million USD to around 1025 million USD in the period 1978-2005 with two periods of sharply rising trends in the 1980s and late 1990s (Fig. 5.3a). Barisal, Khulna and Patuakhali all show similar trends, but Patuakhali currently has a significantly lower GDP (less than 400 million USD) than the others (>1,000 million USD). Per capita income has also risen over the past decades with figures for 2005 showing highest income in Khulna (559 USD/person) followed by Patuakhali (393 USD/person) and Barisal (358 USD/person). Despite crop production accounting for the largest share of total GDP (Fig. 5.3b), fishery and non-ecosystem-based livelihoods (e.g. manufacturing) have seen the largest rises in median income (76 and 8 per cent, respectively), while median income from solely agricultural livelihoods has decreased by 18 per cent. Rising levels of per capita income have resulted in a 17 per cent reduction in the numbers of people classified as living below the upper poverty line since 1995 (Fig. 5.3c). Levels of poverty for Khulna and Barisal in 2010 were 33 and 40 per cent, respectively, of the total population, reductions from 60 and 47 per cent in 1983.

Infant and child mortality have declined 50 and 75 per cent, respectively, in less than two decades (Fig. 5.3d), reflecting the improvement in medical care at births (Fig. 5.3e), access to improved sanitation facilities (Fig. 5.3f) and electricity. Universal access to improved drinking water sources has, however, remained largely unchanged since 1995 (Fig. 5.3g); about five per cent of tube-wells that have been tested across the region show the presence of arsenic, and rising levels of salinity in river and groundwater (see Chaps. 17 and 18) may also be affecting the availability of drinking water (Hossain et al. 2016a). Using the data sources identified in Table 5.2, there has been a significant increase in both male and female education (Fig. 5.3h), although societal participation (as indicated by the percentage of women who read newspapers weekly) has declined two per cent between 1993 and 2010.

Where there are observed improvements in human well-being, they are often associated with the poverty alleviation efforts of government and NGOs that have provided access to sanitation, safe drinking water, better health facilities and free primary education (Chowdhury et al. 2013, 2011). The Bangladesh government received more than 8,500 million USD from 1981 to 2012 in foreign aid to develop health, education 

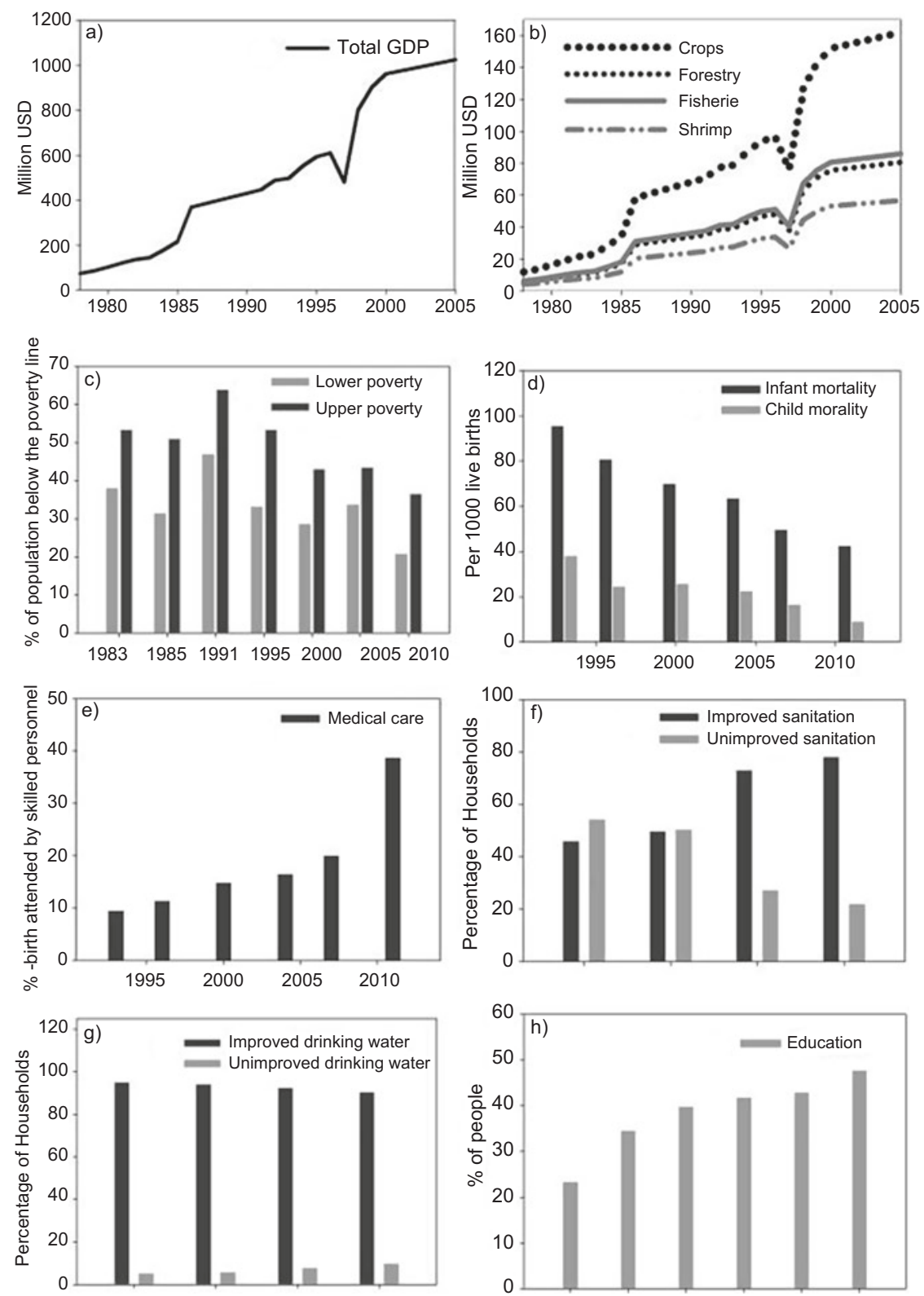

Fig. 5.3 Selected indicators of well-being: (a) total regional GDP, (b) share of GDP across land production sectors, (c) lower and higher poverty level, (d) infant and child mortality, (e) trained medical care at births, (f) improved and unimproved sanitation, (g) improved and unimproved drinking water, (h) uptake of education (see Hossain et al. 2016a for data sources) 
and family planning sectors and now allocates around 20 per cent of the annual national budget each year to these sectors. Other government investment in commercial sectors such as agriculture, industry, energy and rural development has also supported the eradication of poverty (UNDP 2014).

\subsubsection{Links Between Ecosystem Services and Well-Being}

The importance of natural ecosystem products (e.g. timber, honey, wild caught fish) to well-being is probably low and declining yet is an important safety net for the poorest households, as described in Chap. 2. Forest Department records of the total revenue derived from the harvested product (e.g. timber, honey, etc.) of the Sundarbans show a steep decline since the 1990s which, although estimated to represent a small fraction of the value added income from agriculture and aquaculture, represents a significant safety net for poorer populations. Wild fish catches in rivers have also declined substantially in contrast to the rising trend of fish cultivation in ponds (FAO 2014). Over the whole period, provisioning services have increased due to rising agricultural and fisheries productivity. Poverty has however reduced, with many hypothesised explanations emphasising changing access to migration, literacy and health outcomes. The land use shift to value added crops and shrimp farming may have also played a role in poverty reduction. But, as observed previously, in recent times there are contrasts between rising provisioning services and livelihood incomes in different sectors.

For agriculture, the decrease of nearly one-third in the average cultivated area at the household level coupled to a two-fold increase in crop yield points strongly to agricultural intensification. Farmers have adopted high-yielding crops which demand more fertiliser, pesticides and other inputs compared to the traditional local rice varieties (Hossain et al. 2016a, 2013; Ali 1999) resulting in a seven-fold increase in production costs. This increase in production costs and the lack of fair pricing, it is argued, are the main reasons for the falling median incomes of agricultural households (Hossain et al. 2013; IFPRI 2013). However, the situation is complicated. The salinity increase due to shrimp farming also 
reduces crop production and creates unemployment for landless farmers because of the low labour demand in shrimp farming compared to crop production (Swapan and Gavin 2011). As a result, farmers are more likely to belong to the poor income groups. This suggests strongly that regional poverty alleviation has not been driven by natural ecosystem products or agricultural intensification but rather incomes generated from aquaculture, especially shrimp farming, non-ecosystem service sectors and the national investment in infrastructure, education and health care.

To what extent these multi-decadal changes have been driven by external environmental changes is difficult to quantify or determine with certainty. Within the region there are multiple interacting drivers that include global climate change, the take up of new agricultural methods, national infrastructural developments and local-national policy. Some interactions are strong, direct and linear, while others are weaker, nonlinear and may include feedback loops. For example, correlation analysis suggests that climate has directly helped to promote the uptake of highyielding rice varieties as these are adaptable to rising temperatures and the declining rainfall trend in the pre-monsoon season; traditional varieties are now less viable. In contrast, the conversion of rice fields into productive brackish shrimp farming appears to have been favoured by the rising salinity levels of both soils and water sources. Salinisation is related to the relative rise in sea level and eastwards migration of the main river courses, but has been accelerated by polderisation (Swapan and Gavin 2011; Islam 2006; Mirza and Ericksen 1996) and flood control projects from the 1960s onwards particularly the Farakka Barrage (Mirza 1997, 1998). In turn, shrimp farming tends to increase local soil salinity levels thus generating a positive feedback loop between land use change and environmental degradation (Rahman et al. 2013).

\subsubsection{Links Between Provisioning and Regulating Services}

Even though poverty levels among farmers remain high, indicators for average well-being and provisioning services paint a fairly positive picture. In contrast, there is ample evidence to argue that non-food ecosystem 
services such as water availability, water quality, biodiversity and land stability have declined, at least in comparison with conditions in the 1960s.

These opposing trends (Fig. 5.4) constitute a trade-off between wealth creation and poverty alleviation and unsustainable land use. It is also clear that this relationship (known as an environmental Kuznets curve, see Dinda 2004) shows no turning point towards lower levels of environmental degradation while poverty continues to lessen as seen in many middle- and high-income countries (Hossain et al. 2016a). Such unsustainable conditions coupled with the clear evidence for later monsoons and higher temperatures should signal a need for proactive adaptive strategies. As Raudsepp-Hearne et al. (2010) have argued, the growing losses of regulating (and supporting) services may eventually be expected to feedback negatively on essential provisioning services, which in coastal Bangladesh would be expected to drive declines in rice, shrimp and fish production. This would impact first on the poorest sector, the rural

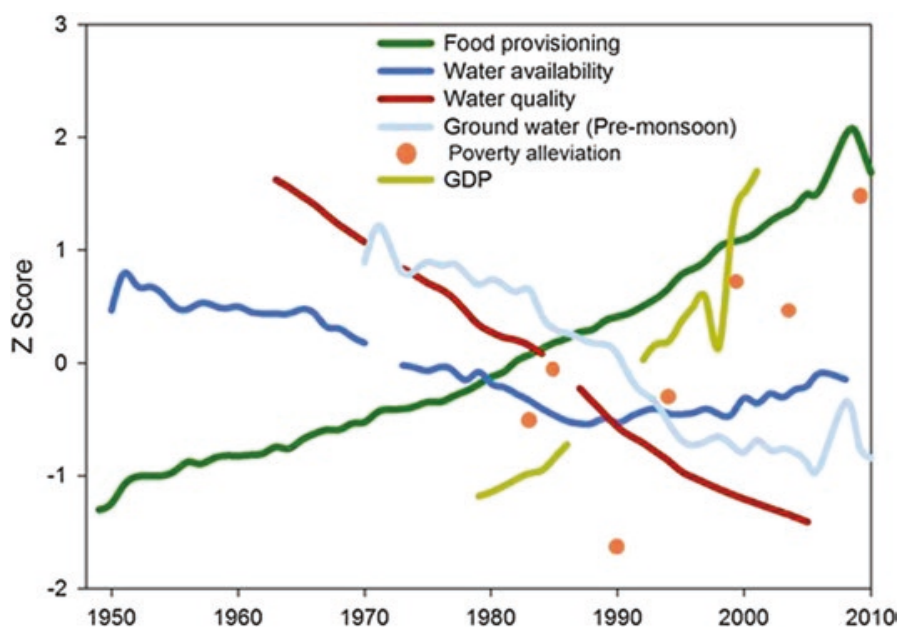

Fig. 5.4 A schematic summary of provisioning services, regulating services, wealth and poverty alleviation 1950-2010. The contrasting curves of normalised data represent a 'trade-off' between rising levels of food production, average wealth and well-being across the region against a background of deteriorating aspects of water (see also Hossain et al. 2016a) 
farmers, still dependent on both wage income and subsistence products, before gradually affecting other sectors, the larger landowners and associated processing industries.

\subsection{Regional Resilience}

In dynamical terms, the most striking feature about the data is the dominance of trending rather than stationary curves. The rise in GDP is the most dramatic as it occurs in less than half the timescale of the others. In longer time-series, the shifts towards deteriorating trends in climate drivers and regulating services occurred in the mid-1970s (water availability), mid-1980s (water quality), early 1980s and 2007 (rainfall), mid-1970s temperature and early 1990s (groundwater level). Shifts towards improving trends of provisioning services occurred in the 1980s. The presence of trends over decadal timescales indicates that many variables have an underlying 'slow' component possibly driven by positive feedback loops. But some variables also show fast or high-frequency components over annual and shorter timescales, particularly water quality, rainfall and water availability. System resilience depends upon the interactions between fast and slow variables. The observation that many of the slowly changing non-food ecosystem services that regulate and support key ecosystem processes are deteriorating may indicate weakening resilience within the dependent agriculture and aquaculture sectors. This is especially important because historical analysis shows that flooding and severe cyclones, particularly in 1987-1988, 1991 and 2007, were the major shocks in the past that have impacted negatively on food production and the poorest communities in the past. Lower levels of resilience and projections of higher incidences of climate shocks (e.g. Khan et al. 2000; Ali 1999) raises the prospect of 'perfect storm' scenarios (Dearing et al. 2012) with a greater likelihood of negative impacts in the future. Dynamic and integrated modelling approaches that can guide the selection of adaptation and sustainable management options for the coming decades will be essential to address these concerns. 


\section{Notes}

1. available from http://microdata.worldbank.org

2. https://marine.rutgers.edu/globalnews/datasets.htm

\section{References}

Ali, A. 1999. Climate change impacts and adaptation assessment in Bangladesh. Climate Research 12 (2-3): 109-116. https://doi.org/10.3354/cr012109.

BBS. 2012. Bangladesh population and housing census 2011 - Socio-economic and demographic report. Report national series, vol. 4. Dhaka: Bangladesh Bureau of Statistics (BBS) and Statistics and Informatics Division (SID), Ministry of Planning, Government of the People's republic of Bangladesh. http://www.bbs.gov.bd/PageSearchContent.aspx?key=census\%202011. Accessed 7 July 2016.

Brammer, H. 2014. Bangladesh's dynamic coastal regions and sea-level rise. Climate Risk Management 1: 51-62. https://doi.org/10.1016/j.crm.2013. 10.001 .

CEGIS. 2007. Effect of cyclone sidr on the Sundarbans: A preliminary assessment. Dhaka: Center For Environmental and Geographic Information Services (CEGIS).

Chaffey, D.R., F.R. Miller, and J.H. Sandom. 1985. A forest inventory of the Sundarbans, Bangladesh. Project report no 140. Land Resources Development Centre, England: Overseas Development Administration.

Chowdhury, Q. 2001. State of Sundarban. In Forum of environmental journalist of Bangladesh, ministry of environment and forest, Bangladesh (MoEF). Dhaka: United Nations Development Program (UNDP).

Chowdhury, S., L.A. Banu, T.A. Chowdhury, S. Rubayet, and S. Khatoon. 2011. Achieving millennium development goals 4 and 5 in Bangladesh. Bjog-an International Journal of Obstetrics and Gynaecology 118: 36-46. https://doi.org/10.1111/j.1471-0528.2011.03111.x.

Chowdhury, A.M.R., A. Bhuiya, M.E. Chowdhury, S. Rasheed, Z. Hussain, and L.C. Chen. 2013. The Bangladesh paradox: Exceptional health achievement despite economic poverty. The Lancet 382 (9906): 1734-1745. https:// doi.org/10.1016/s0140-6736(13)62148-0.

Dearing, J.A., S. Bullock, R. Costanza, T.P. Dawson, M.E. Edwards, G.M. Poppy, and G.M. Smith. 2012. Navigating the perfect storm: Research strategies 
for socialecological systems in a rapidly evolving world. Environmental Management 49 (4): 767-775. https://doi.org/10.1007/s00267-012-9833-6.

Dey, T.K. 2007. Deer population in the Bangladesh Sundarban. Chittagong: The Ad Communication.

Dinda, S. 2004. Environmental Kuznets curve hypothesis: A survey. Ecological Economics 49 (4): 431-455. https://doi.org/10.1016/j.ecolecon. 2004.02.011.

Ericksen, N.J., Q.K. Ahmad, and A.R. Chowdhury. 1996. Socio-economic implications of climate change for Bangladesh. In The implications of climate and sea-Level change for Bangladesh, ed. R.A. Warrick and Q.K. Ahmad, 205-287. Dordrecht: Springer.

FAO. 1999. Forest resources of Bangladesh. Country report, working paper no. 15. Rome: Food and Agricultural Organization of the United Nations (FAO). 2007. Mangroves of Asia 1980-2005. Country reports. Forest resources assessment programme, working paper 137. Rome: Food and Agriculture Organization of the United Nations (FAO). ftp://ftp.fao.org/docrep/fao/010/ ai444e/ai444e00.pdf. Accessed 3 Jan 2013.

. 2014. The state of world fisheries and aquaculture: Opportunities and challenges. Rome: Food and Agriculture Organization of the United Nations (FAO). http://www.fao.org/3/d1 eaa9a1-5a71-4e42-86c0-f2111f07de16/ i3720e.pdf. Accessed 5 July 2016.

Gittins, S.P. 1980. A survey of the primates of Bangladesh. In Project report to the forest department of Bangladesh. London: Flora and Fauna Preservation Society.

Helalsiddiqui, A.S.M. 1998. Sundarban at a glance. Khulna: Mangrove Silviculture Division, Bangladesh Forest Research Institute.

Hendrichs, H.H. 1975. The status of the tiger Panthera Tigris (Linné, 1758) in the Sundarbans mangrove forest (Bay of Bengal). Säugetierekundliche Mitteilungen 23 (3): 161-199.

Hossain, M.S., M.J. Uddin, and A.N.M. Fakhruddin. 2013. Impacts of shrimp farming on the coastal environment of Bangladesh and approach for management. Reviews in Environmental Science and Bio-Technology 12 (3): 313-332. https://doi.org/10.1007/s11157-013-9311-5.

Hossain, M.S., F. Amoako Johnson, J.A. Dearing, and F. Eigenbrod. 2016a. Recent trends of human wellbeing in the Bangladesh delta. Environmental Development 17: 21-32. https://doi.org/10.1016/j.envdev.2015.09.008.

Hossain, M.S., J.A. Dearing, M.M. Rahman, and M. Salehin. 2016b. Recent changes in ecosystem services and human well-being in the Bangladesh coastal zone. Regional Environmental Change 16 (2): 429-443. https://doi. org/10.1007/s10113-014-0748-z. 
IFPRI. 2013. The status of food security in the feed the future zone and other regions of Bangladesh. Results from the 2011-2012 Bangladesh integrated household survey. Dhaka: International Food Policy Research Institute. http://www.fao. org/family-farming/detail/en/c/417259/. Accessed 06 Jan 2017.

Iftekhar, M.S., and M.R. Islam. 2004. Degeneration of Bangladesh's Sundarbans mangroves: A management issue. International Forestry Review 6 (2): 123-135. https://doi.org/10.1505/ifor.6.2.123.38390.

Iftekhar, M.S., and P. Saenger. 2008. Vegetation dynamics in the Bangladesh Sundarbans mangroves: A review of forest inventories. Wetlands Ecology and Management 16 (4): 291-312. https://doi.org/10.1007/s11273-007-9063-5.

Islam, M.R. 2006. Managing diverse land uses in coastal Bangladesh: Institutional approaches. In Environment and livelihoods in tropical coastal zones: Managing agriculture-fishery-aquaculture conflicts, ed. C.T. Hoanh, T.P. Tuong, J.W. Gowing, and B. Hardy. Wallingford: CAB International.

Islam, N. 2007. Exploring the drivers for conversion of agricultural land to shrimp farms in south-west region of Bangladesh. MSc thesis, Environmental Science Discipline, Khulna University.

Islam, M.S.N. 2008. Cultural landscape changing due to anthropogenic influences on surface water and threats to mangrove wetland ecosystems: A case study on the Sundarbans. PhD thesis, Faculty of Environmental Sciences and Process Engineering, Brandenburg University of Technology.

Islam, M.B., M.Y. Ali, M. Amin, and S.M. Zaman. 2011. Climatic variations: Farming systems and livelihoods in the high Barind tract and coastal areas of Bangladesh. In Climate change and food security in South Asia, ed. Lal Rattan, V.K. Mannava Sivakumar, S.M.A. Faiz, A.H.M. Mustafizur Rahman, and R. Khandakar Islam, 477-497. Dordrecht: Springer.

IUCN. 1997. Sundarban wildlife sanctuaries (Bangladesh). IUCN technical evaluation. Gland: International Union for Conservation of Nature (IUCN). http://whc.unesco.org/archive/advisory_body_evaluation/798.pdf. Accessed 20 Jan 2013.

Khan, M.M.H. 2005. Project Sundarban tiger: Tiger D=density and tiger-human conflict. Financial technical report. Washington, DC: Save The Tiger Fund of the National Fish and Wildlife Foundation. http://www.panthera.org/sites/ default/files/STF/2005-0013-004.pdf. Accessed 2 Apr 2013.

Khan, T.M.A., O.P. Singh, and M.R. Sazedur. 2000. Recent sea level and sea surface temperature trends along the Bangladesh coast in relation to the frequency of intense cyclones. Marine Geodesy 23 (2): 103-116. https://doi. org/10.1080/01490410050030670. 
MDG. 2015. Millennium development goals. Bangladesh progress report 2015. Dhaka: General Economics Division, Bangladesh Planning Commission, Government of the People's Republic of Bangladesh. http://www.bd.undp. $\mathrm{org} /$ content/bangladesh/en/home/library/mdg/mdg-progress-report-2015. html. Accessed 11 Jan 2017.

MEA. 2005. Ecosystems and human well-being: Synthesis. Millennium ecosystem assessment (MEA). Washington, DC: Island Press. http://www.millenniumassessment.org/documents/document.356.aspx.pdf. Accessed 01 Aug 2016.

Mirza, M.M.Q. 1997. Hydrological changes in the Ganges system in Bangladesh in the post-Farakka period. Hydrological Sciences Journal 42 (5): 613-631. https://doi.org/10.1080/02626669709492062.

- 1998. Diversion of the Ganges water at Farakka and its effects on salinity in Bangladesh. Environmental Management 22 (5): 711-722. https://doi. org/10.1007/s002679900141.

Mirza, M.Q., and N.J. Ericksen. 1996. Impact of water control projects on fisheries resources in Bangladesh. Environmental Management 20 (4): 523-539. https://doi.org/10.1007/bf01474653.

MoEF. 2002. Survey to determine the relative abundance of tiger wild boar and spotted deer in the Bangladesh Sundarban forest during December 2001-March 2002. Technical reports-TR no.17. Dhaka: Ministry of Environment and Forest (MoEF), Government of the People's Republic of Bangladesh.

. 2010. Fourth national report to the convention on biological diversity. Biodiversity national assessment and programme of action 2020. Dhaka: Ministry of Environment and Forests (MoEF). www.cbd.int/doc/world/bd/ bd-nr-04-p1-en.pdf. Accessed 5 July 2016.

OECD. 2013. Guidelines on measuring subjective well-being. Paris: OECD Publishing. https://doi.org/10.1787/9789264191655-en.

Rahman, A., G. Rabbani, M. Muzammil, M. Alam, S. Thapa, R. Rakshit, and H. Inagaki. 2010. Scoping assessment on climate change adaptation in Bangladesh. Report prepared by the Bangladesh center for advanced studies. Bangkok: AIT-UNEP RRC.AP.

Rahman, M.H., T. Lund, and I. Bryceson. 2011. Salinity impacts on agrobiodiversity in three coastal, rural villages of Bangladesh. Ocean and Coastal Management 54 (6): 455-468. https://doi.org/10.1016/j. ocecoaman.2011.03.003.

Rahman, M.M., V.R. Giedraitis, L.S. Lieberman, T. Akhtar, and V. Taminskiene. 2013. Shrimp cultivation with water salinity in Bangladesh: The implications of an ecological model. Universal Journal of Public Health 1 (3): 131-142. http://dx.doi.org/10.13189/ujph.2013.010313. 
Raudsepp-Hearne, C., G.D. Peterson, M. Tengö, E.M. Bennett, T. Holland, K. Benessaiah, G.K. MacDonald, and L. Pfeifer. 2010. Untangling the environmentalist's paradox: Why is human well-being increasing as ecosystem services degrade? Bioscience 60 (8): 576-589. https://doi.org/10.1525/ bio.2010.60.8.4.

Salim, M., B.U. Maruf, M. Sumsuddoha, A.I. Chowdhury, and A.R. Babul. 2007. Climate change would intensify river erosion in Bangladesh: Climate change impact in Bangladesh. In Equity and justice working group, campaign brief 6. Dhaka: COAST Trust.

Swapan, M.S.H., and M. Gavin. 2011. A desert in the delta: Participatory assessment of changing livelihoods induced by commercial shrimp farming in Southwest Bangladesh. Ocean and Coastal Management 54 (1): 45-54. https://doi.org/10.1016/j.ocecoaman.2010.10.011.

Uddin, M.N., and A. Haque. 2010. Salinity response in southwest coastal region of Bangladesh due to hydraulic and hydrological parameters. International Journal of Sustainable Agricultural Technology 6 (3): 1-7.

UN. 2015. Sustainable development goals (SDGs). United Nations (UN). http:// www.un.org/sustainabledevelopment/. Accessed 22 Sept 2017.

UNDP. 2014. Human development report 2014. Sustaining human progress: Reducing vulnerabilities and building resilience. New York: United Nations Development Program (UNDP). http://hdr.undp.org/en/content/humandevelopment-report-2014. Accessed 5 July 2016.

Wodon, Q.T. 1997. Food energy intake and cost of basic needs: Measuring poverty in Bangladesh. Journal of Development Studies 34 (2): 66-101. https://doi.org/10.1080/00220389708422512.

Zmarlicki, C.B. 1994. Integrated resources development of the Sundarbans Reserved Forest, Bangladesh. Rome: United Nations Development Programme (UNDP) and Food and Agriculture Organization of the United Nations (FAO). 
Open Access This chapter is licensed under the terms of the Creative Commons Attribution 4.0 International License (http://creativecommons.org/licenses/ by/4.0/), which permits use, sharing, adaptation, distribution and reproduction in any medium or format, as long as you give appropriate credit to the original author(s) and the source, provide a link to the Creative Commons license and indicate if changes were made.

The images or other third party material in this chapter are included in the chapter's Creative Commons license, unless indicated otherwise in a credit line to the material. If material is not included in the chapter's Creative Commons license and your intended use is not permitted by statutory regulation or exceeds the permitted use, you will need to obtain permission directly from the copyright holder.

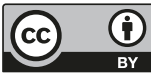

